\title{
Value System and Value Preferences of Prospective Teachers of Secondary Schools: An Indian Survey
}

\author{
Rajendra Prasad Dasari
}

Department of Education, Kakatiya University, India

Copyright $\subseteq 2017$ by authors, all rights reserved. Authors agree that this article remains permanently open access under the terms of the Creative Commons Attribution License 4.0 International License

\begin{abstract}
Present society needs a moral, more sustaining order in every sphere of life to have a firm foundation for further human progress. School education touches the chord of ethical conduct of children as it plays a vital role in the inculcation of right values. This will stand them in good stead as they grow up. As adults, they can practice the values in social life which they imbibed at a formative stage. Hence, value education should be the primary concern of teacher preparation because a teacher has the responsibility of shaping children thoughts which decide their behaviour, and actions later on in their life. The present study examines the value system and value preferences of the prospective teachers. A sample of 330 preservice teachers of B.Ed. programme was randomly selected, and Rokeach Value Survey (RVS) was adopted for the study. The study reveals that the prospective teachers are self-oriented towards the end state of their existence showing their inclination towards freedom, comforts, and friendship. However, it is found that their modes of conduct are much oriented towards hard working nature with duty consciousness and open-mindedness. The study suggests that the curriculum and instruction should provide necessary inputs into theory and practical work to make preservice teachers realize the importance of values of equality, peace, self-respect, and honesty.
\end{abstract}

Keywords Prospective Teachers, Values, B. Ed. Programme

\section{Introduction}

Values are the foundation of a social structure deciding its nature and characteristics. Values are both integral to and essential part of any organization. Values are manifested in the entire range of social spectrum - its institutions and other organizational structures. Human behaviour and actions are decided by their beliefs and value system. Value preferences and value system of teachers determine their thought, speech, and actions which influence not only the students but also the whole school system. The world faces different challenges of anarchy, oppression, racial, religious, sectarian conflicts, corruption, violence and war. Teachers and the schools have to be reoriented so that teaching-learning process goes beyond content knowledge of the courses in a programme to realize the values of higher order of freedom, equality, compassion and sense of oneness to make the world a global, peaceful community.

The frontiers of teacher education are expanding immensely in recent years. There is a pervasive criticism of this quantitative expansion at the cost of quality in India. A number of teacher education institutions do not have adequate physical and human resources in the expansion process. Further, some of the private institutions coming up with a modicum of concern for quality. In such a situation, only teacher educators having concern for values could save the future of teacher education. Hence, teacher education institutions should shoulder the responsibility of producing teachers with values of higher order to practice them at their schools. Transmitting these values from teacher educators to school students through teacher trainees is a continuous process. The forty sixth session of the International Conference on Education that took place duirng 5-8 September, 2001 in Geneva on the theme 'learning to live together' pleaded for improving the education of teachers so that they can better develop behaviour, values of solidarity and tolerance among the student community. It is necessary to prevent and resolve conflicts peacefully and to respect cultural diversity [1]. Change of values is a universal phenomenon because of political and economic changes that take place in society. But, the inner core of values which lead to peace and happiness of human beings, an essential indicator of the development of human society, will remain the same.

\section{A Review}

The Fifth Survey of Educational Research [2] reported thirty-one studies in the area of moral, art and aesthetic 
education of which only two are related to teachers' values. The Sixth Survey of Educational Research [3] stated that the area of value measurement had remained an illusory one as far as Indian Research is concerned. The Survey has identified only eight studies related to values of teachers and student teachers. The Eighty First Parliamentary Committee Report [4] had elaborately dwelt upon the nature of desired value education programmes and the need to develop strategies for implementation of these programmes.

According to Rokeach [5] "A value is an enduring belief that a specific mode of conduct or end state of existence is personally or socially preferable to an opposite or converse mode of conduct or end state of existence". Values are regarded as belief-systems that transcend specific situations, and they function as standards of conduct. Values are central constructs and related more closely to basic human needs and societal demands. Rokeach, M, Norman T. Feather and others [6] have done extensive research relating the value survey to a wide range of demographic, attitudinal and behavioural factors, both in correlational and longitudinal studies. In general, the value survey seems to be both a reliable, valid measure of values and value systems.

A poll of adult Americans conducted by The Wall Street Journal stated, 'moral decline' as the biggest problem America faces in the next twenty years as over ninety percent of Americans believed a significant 'moral decline' in the country [7]. Almost all societal problems can be reduced to the failure to do something, and people make mistakes as a result of inaccurate information or a lack of information. Since the school transmits knowledge, skills, and values it is regarded as critical within the society and held accountable when problems arise [8]. Teachers believed that the schools should be concerned with values. They did not believe in planning value education and preferred to use examples and discussions for the inculcation of values [9].

Rajendra Prasad [10] found that the more preferred terminal values of the school teachers were peace, freedom and comfortable life. The study also found that their more preferred instrumental values were honesty, independence, and courageousness. Ray [11] study revealed that the more preferred terminal values of the teachers were freedom, equality, the world at peace, happiness and true friendship. The study found that the more preferred instrumental values were honesty, love, obedience, responsibility and helpfulness. Australian teachers and American teachers embrace similar democratic value systems regarding their top five values but vary in several of the values [12]. Janusz Stanek [13] study related to values preferred by teachers and students for teacher training faculties identified two values-wisdom, and honesty. Teacher educators and preservice teachers of the teacher education programme had given preference to the terminal values, equality, and exciting life. However, professors ranked the value 'a world at peace' a more preferred one. The students had given the least importance to the same. The values of capability and helpfulness were more preferred instrumental values of professors while that of students were independence and politeness [14]. Rajendra Prasad [15] found that teacher educators' orientation was more towards values of equality, peace, and comfort. The values of self-respect, competence, independence and imagination were consequential to the teacher educators but of little relevance to the students. In respect of the value of competence, nearly one-fourth of the students did not perceive it to be crucial for personal success. However, teacher educators ranked competence very high. A clash of values is possible unless strategies for intervention are applied [16].

Pre-service teacher beliefs are important and teacher education should be oriented towards the formation of beliefs [17]. Mergler and Spooner-Lane [18] argued for some changes in pre-service teacher training with values focus. Usha Sri [19] study suggested a curricular component of value education paper for the B.Ed. Programme comprising twelve units covering all aspects of value education. Singh and Singh [20] found that Value Clarification Strategies (VCS) are more efficient than conventional methods in the inculcation of values of dedication, cooperation, nationalism, and scientific outlook. Rajendra Prasad [21] found that the more preferred terminal values of M.Ed. students were the world at peace, equality, and wisdom. And, the more preferred instrumental values were ambition, helpfulness, and honesty. Kakkar [22] study on the values among teacher trainees and college teachers reported significant differences in economic, aesthetic and social values and no significant differences in theoretical, political and religious values among teacher trainees and teacher educators. Male and female prospective teachers uniformly assigned great importance to self-control, obedience, and honesty. Female prospective teachers ranked forgiveness, ambition, helpfulness, and lovingness higher than their male counterparts while male teachers ranked logic, courage, capability, responsibility, imagination and independence higher. Highest importance to self-control and honesty and least importance to logic and capability were given by female prospective teachers. Utmost importance to intellectuality and least to broadmindedness was given by male prospective teachers [23]. Nayyar [24] study revealed that the student-teachers' most important values were justice, discipline, and honesty. Oguz [25] study found that preservice teachers mostly agreed with universalism, benevolence, security and least preference was given to stimulation, hedonism, and conformity. Alkin and others [26] concluded that there is a meaningful level of relation between teachers' professional values and critical thinking disposition.

Values are socially approved principles that are internalized mainly through the process of education. They are reflected in human beliefs, culture, customs, and practices. Values are regarded as abstract beliefs that transcend specific situations, objects, and issues, and function as standards of conduct as compared to attitudes which are evaluative judgments related to specific issues and 
situations. There should be coherence and continuity of core values in human society and more particularly in the education system. It demands continuous research on value orientation among teacher educators, prospective teachers, school teachers, and students so that the values are known, understood and necessary curricular and instructional changes are made to restore the core values of education whenever it requires. The present study examines the value system and value preferences of the prospective teachers about terminal values, which represent the end-states of existence and instrumental values which also represent modes of conduct. The terminal values included a comfortable life, an exciting life, a world at peace, equality, family security, freedom, happiness, pleasure, self-respect, social recognition, true friendship, and wisdom. The instrumental values included ambition, broadmindedness, capability, courage, forgiveness, helpfulness, honesty, independence, intellect, obedience, politeness and responsibility.

\section{Study Procedure}

A sample of 330 students was randomly selected from 6 colleges pursuing B.Ed. Programme under Kakatiya University. It included male $(94,28.5 \%)$ and female $(236$, $71.5 \%)$; married $(93,28 \%)$ and unmarried $(237,72 \%)$; science $(198,60 \%)$ and social studies $(132,40 \%)$ methodology; Hindu (190, 57.6\%), Muslim (85, 25.8\%) and Christian $(55,16.6 \%)$; urban $(133,40.3 \%)$, rural $(134,40.6 \%)$ and tribal $(63,19.1 \%)$ prospective teachers.

The instrument included Rokeach Value Survey (RVS) with terminal and instrumental values, each with a list of 12 values mostly related to teaching profession, looking into the common judgment of the experts. The values in both sets are arranged in alphabetical order. Terminal values are presented before the instrumental values. The responses were solicited from prospective teachers in order of their own preferences guiding their life, 1 to 12 against each value for each set of values. A brief introduction of the study had been given by the researcher before the research tool was served to the participants at the time of completion of their B.Ed. programme. The reliability coefficient of 0.93 for terminal values and 0.98 for instrumental values using the split-half method, had established high reliability. The validity coefficient of 0.96 for terminal values and 0.97 for instrumental values using item analysis, indicated high validity. Hence, the tool is adopted, and normalized rank order method was applied in the study.

\section{Findings and Discussion}

The data collected by administering the tool is presented in the tables 1 and 2. Normalized-rank order method was applied in which the sums of the rank values for various values gives the best indication of ranking. $\mathrm{C}$-scale values are provided for different numbers ranked (n), in the table. The sum of the product of total preferences and C-values calculated is represented by $\sum f_{j i} C$. The means of $\sum f_{j i} C$ are computed, known as response value $R_{j}$. Based on the means of 12 values the rank order is given for each value. Highest mean value is given rank 1 , and the lowest one is given rank 12 in the tables 1 and 2 for terminal and instrumental values, respectively (Appendix-1 \& 2).

Table 1 reveals the rank order of terminal values of prospective teachers. The order of preference of terminal values is observed as follows:

1. Freedom (Independence, free choice)

2. A comfortable life (A Prosperous life)

3. True Friendship (Close companionship)

4. Wisdom (A mature understanding of life)

5. Equality (Brotherhood, equal opportunity for all)

6. An exciting life (A stimulating, active life)

7. Pleasure (An enjoyable, leisurely life)

8. Social Recognition (Respect, admiration)

9. Family security (Taking care of loved ones)

10. Self-respect (Self-esteem)

11. Happiness (Contentedness)

12. A world at peace (Free of war and conflict)

Table 2 reveals the rank order of instrumental values of prospective teachers. The order of preference of instrumental values is observed as follows:

1. Ambition (Hard working, aspiring)

2. Broadminded (Open minded)

3. Obedient (Dutiful, respectful)

4. Courageous (Standing up for beliefs)

5. Polite (Courteous, well-mannered)

6. Capable (Competent, effective)

7. Helpful (Working for the welfare of others)

8. Responsible (Dependable, reliable)

9. Forgiving (Willing to pardon others)

10. Honest (Sincere, truthful)

11. Intellectual (Intelligent, reflective)

12. Independent (Self-reliant, self-sufficient)

The more preferred and less preferred terminal and instrumental values of the prospective teachers are represented in Table 3 (Appendix-3).

The more preferred terminal values of prospective teachers are in the order of:

1. Freedom (Independence, free choice)

2. A comfortable life (A Prosperous life)

3. True Friendship (Close companionship).

The less preferred terminal values of them are in the order of:

1. A world at peace (Free of war and conflict)

2. Happiness (Contentedness)

3. Self-respect (Self-esteem).

The more preferred instrumental values of prospective teachers are in the order of:

1. Ambition (Hard working, aspiring) 
2. Broadminded (Open minded)

3. Obedient (Dutiful, respectful).

The less preferred instrumental values of them are in the order of:

1. Independent (Self-reliant, self-sufficient)

2. Intellectual (Intelligent, reflective)

3. Honest (Sincere, truthful).

Part of socialization of child is the inculcation of values. Education is integrally linked with the social order. Intellectual development of an individual and inculcation of the desired values among them gets higher priority for a better social order. The school teachers have to be trained in a value system so that they embrace right values and impart them to the students while taking the curriculum as a voyager. In this context, the study of values of preservice teachers is of significance. The present study had been undertaken to understand the value system and value preferences of preservice teachers of secondary schools. The results show that the prospective teachers had given top priority to the terminal value, freedom followed by a comfortable life and true friendship. Their conceptualization of freedom seems to have a correlation with the other two preferred valuescomfortable life and true friendship rather than freedom in the society. This preference order reveals that their personal values took priority over professionally and socially related values like wisdom, self-respect, exciting life, equality, social recognition and a world at peace. The results are in agreement with the study results of Escobar-Ortloff \& Ortloff (2000) with regard to a world at peace.This situation is of great concern which needs a further probe to address the problem so that professional and social values take priority. However, they had given less preference to pleasure, family security and happiness may be because they were cared and financially supported either by their parents or spouse while they were undergoing the programme, and hence found to be more secured and happy enjoying the period of teacher education programme. With regard to instrumental values, the results show that the prospective teachers had given top priority to ambition followed by broadmindedness and obedience revealing that these values dominate their mode of conduct. This order of preference reveals that they are open minded, ready to work hard and dutiful. They took priority over values like courageousness, politeness, capableness, helpfulness, responsibility and forgiveness in the the behaviour of prospective teachers. They least preferred the value of independence followed by intellectuality and honesty showing that their mode of behaviour was oriented towards dependency and not towards intellectual endeavour and honesty. The result are in disagreement with the study results of Nayyar (1989) with regard to honesty. The curriculum and instruction of preservice teacher education programme appear to have not influenced their outlook towards social responsibilities of attainment of equality and peace in the world. Preservice teachers less concern towards self-respect, intellect, and honesty, the core values of teacher preparation, reveals that there is a need for relooking into the entire procedures and practices of teacher education in India for inculcation of these values.

\section{Conclusions}

The study revealed that the prospective teachers were self-oriented towards the end-state of existence showing inclination towards their freedom, comfort, and friendship. However, it is found that their modes of conduct were much oriented towards hard working nature with duty consciousness and open-mindedness. They did not realize the importance of social values like equality and peace. However, attainment of these values is the primary objective of education. The prospective teachers' values are to be reoriented in this direction because their value system and preferences are going to influence the students in the classroom and the society at large. The curriculum and instruction provided to the prospective teachers should recognize their hard-working nature, duty consciousness and open-mindedness to provide necessary curricular inputs into theory, project and community works to make them realize the ultimate aims of achieving equality, peace and harmony in the society. Taking such steps to orient the future teachers will keep them to go beyond the content to inculcate the hidden values of equality, peace in their school subjects. The teacher educators should also to be trained in this direction to give right inputs while training the prospective teachers. They should also be trained to teach how the subject teaching at school level can be integrated with value education. The preservice teachers least concern about self-respect, intellect, and honesty shows that the training activities should be rigorous with the outcome behavioural objectives rather than mere interpretation of subject content in the evaluation procedures. Commercialization of teacher education programmes should be curbed to restore quality of teacher education in India through better instruction and standard evaluation procedures. Curricular interventions in preservice teacher preparation are also needed to train the prospective teachers realize the importance of inculcation of values among school children. Teacher educators should take care of inculcating the values of democracy, equality and fraternity in the prospective teachers which are stated in the preamble of the Indian Constitution. The study suggests further research to know the values incorporated in the preservice teacher education curriculum and the values among teacher educators of these institutions. 


\section{Appendix 1}

Table 1. Rank Order of Terminal Values of Prospective Teachers ( $n=330)$

\begin{tabular}{|c|c|c|c|c|c|}
\hline $\begin{array}{l}\text { Sl } \\
\text { No. }\end{array}$ & Terminal Values & $\begin{array}{l}\text { C Scale } \\
\text { Value }\end{array}$ & $\sum f_{j i} C$ & $M_{c}\left(R_{j}\right)$ & $\begin{array}{l}\text { Rank } \\
\text { Order }\end{array}$ \\
\hline 1 & $\begin{array}{l}\text { A comfortable life } \\
\text { (A Prosperous life) }\end{array}$ & 8 & 1691 & 5.12 & 2 \\
\hline 2 & $\begin{array}{c}\text { An exciting life } \\
\text { (A stimulating, active life) }\end{array}$ & 7 & 1644 & 4.98 & 6 \\
\hline 3 & $\begin{array}{c}\text { A world at peace } \\
\text { (Free of war and conflict) }\end{array}$ & 7 & 1593 & 4.83 & 12 \\
\hline 4 & $\begin{array}{c}\text { Equality } \\
\text { (Brotherhood, equal opportunity for all) }\end{array}$ & 6 & 1649 & 5.00 & 5 \\
\hline 5 & $\begin{array}{c}\text { Family security } \\
\text { (Taking care of loved ones) }\end{array}$ & 6 & 1638 & 4.96 & 9 \\
\hline 6 & $\begin{array}{c}\text { Freedom } \\
\text { (Independence, free choice) }\end{array}$ & 5 & 1699 & 5.15 & 1 \\
\hline 7 & $\begin{array}{c}\text { Happiness } \\
\text { (Contentedness) }\end{array}$ & 5 & 1614 & 4.90 & 11 \\
\hline 8 & $\begin{array}{c}\text { Pleasure } \\
\text { (An enjoyable, leisurely life) }\end{array}$ & 4 & 1640 & 4.97 & 7 \\
\hline 9 & $\begin{array}{c}\text { Self-respect } \\
\text { (Self-esteem) }\end{array}$ & 4 & 1618 & 4.90 & 10 \\
\hline 10 & $\begin{array}{l}\text { Social Recognition } \\
\text { (Respect, admiration) }\end{array}$ & 3 & 1639 & 4.97 & 8 \\
\hline 11 & $\begin{array}{c}\text { True Friendship } \\
\text { (Close companionship) }\end{array}$ & 3 & 1687 & 5.11 & 3 \\
\hline 12 & $\begin{array}{c}\text { Wisdom } \\
\text { (A mature understanding of life) }\end{array}$ & 2 & 1681 & 5.09 & 4 \\
\hline
\end{tabular}

$\sum \mathrm{f}_{\mathrm{ji}} \mathrm{C}$ - Sum of the product of total preferences and $\mathrm{C}$ values

$\mathrm{M}_{\mathrm{c}}-$ Mean, $\mathrm{R}_{\mathrm{j}}-$ Response Value

\section{Appendix 2}

Table 2. Rank Order of Instrumental Values of Prospective Teachers ( $n=330)$

\begin{tabular}{|c|c|c|c|c|c|}
\hline $\begin{array}{l}\text { Sl. } \\
\text { No. }\end{array}$ & Instrumental Values & $\begin{array}{l}\text { C Scale } \\
\text { Value }\end{array}$ & $\sum f_{j i} C$ & $M_{c}\left(R_{j}\right)$ & $\begin{array}{l}\text { Rank } \\
\text { Order }\end{array}$ \\
\hline 1 & $\begin{array}{c}\text { Ambition } \\
\text { (Hard working, aspiring) }\end{array}$ & 8 & 1806 & 5.47 & 1 \\
\hline 2 & $\begin{array}{l}\text { Broadminded } \\
\text { (Open minded })\end{array}$ & 7 & 1702 & 5.16 & 2 \\
\hline 3 & $\begin{array}{c}\text { Capable } \\
\text { (Competent, effective) }\end{array}$ & 7 & 1647 & 4.99 & 6 \\
\hline 4 & $\begin{array}{c}\text { Courageous } \\
\text { (Standing up for beliefs) }\end{array}$ & 6 & 1673 & 5.07 & 4 \\
\hline 5 & $\begin{array}{c}\text { Forgiving } \\
\text { (Willing to pardon others) }\end{array}$ & 6 & 1607 & 4.87 & 9 \\
\hline 6 & $\begin{array}{l}\text { Helpful } \\
\text { (Working for the welfare of others) }\end{array}$ & 5 & 1627 & 4.93 & 7 \\
\hline 7 & $\begin{array}{c}\text { Honest } \\
\text { (Sincere, truthful) }\end{array}$ & 5 & 1605 & 4.86 & 10 \\
\hline 8 & $\begin{array}{c}\text { Independent } \\
\text { (Self-reliant, self-sufficient) }\end{array}$ & 4 & 1578 & 4.78 & 12 \\
\hline 9 & $\begin{array}{c}\text { Intellectual } \\
\text { (Intelligent, reflective) }\end{array}$ & 4 & 1596 & 4.84 & 11 \\
\hline 10 & $\begin{array}{c}\text { Obedient } \\
\text { (Dutiful, respectful) }\end{array}$ & 3 & 1690 & 5.12 & 3 \\
\hline 11 & $\begin{array}{c}\text { Polite } \\
\text { (Courteous, well-mannered) }\end{array}$ & 3 & 1649 & 5.00 & 5 \\
\hline 12 & $\begin{array}{c}\text { Responsible } \\
\text { (Dependable, reliable) }\end{array}$ & 2 & 1620 & 4.91 & 8 \\
\hline
\end{tabular}

$\sum \mathrm{f}_{\mathrm{ji}} \mathrm{C}$ - Sum of the product of total preferences and $\mathrm{C}$ values

$\mathrm{M}_{\mathrm{c}}-$ Mean, $\mathrm{R}_{\mathrm{j}}-$ Response Value 


\section{Appendix 3}

Table 3. Preferences of Terminal and Instrumental Values of Prospective Teachers

\begin{tabular}{|c|c|}
\hline More Preferred Terminal Values & Less Preferred Terminal Values \\
\hline $\begin{array}{l}\text { 1. Freedom } \\
\text { (Independence, free choice) } \\
\text { 2. A comfortable life } \\
\text { (A Prosperous life) } \\
\text { 3. True Friendship } \\
\text { (Close companionship) }\end{array}$ & $\begin{array}{l}\text { 1. A world at peace } \\
\text { (Free of war and conflict) } \\
\text { 2. Happiness } \\
\text { (Contentedness) } \\
\text { 3. Self-respect } \\
\text { (Self-esteem) }\end{array}$ \\
\hline More Preferred Instrumental Values & Less Preferred Instrumental Values \\
\hline $\begin{array}{l}\text { 1. Ambition } \\
\text { (Hard working, aspiring) } \\
\text { 2. Broadminded } \\
\text { (Open minded) } \\
\text { 3. Obedient } \\
\text { (Dutiful, respectful) }\end{array}$ & $\begin{array}{l}\text { 1. Independent } \\
\text { (Self-reliant, self-sufficient) } \\
\text { 2. Intellectual } \\
\text { (Intelligent, reflective) } \\
\text { 3. Honest } \\
\text { (Sincere, truthful) }\end{array}$ \\
\hline
\end{tabular}

\section{REFERENCES}

[1] Unesco. (2002). Educational Innovations and information. International Bureau of Education (IEE), Geneva, Switzerland. $1-5$.

[2] Fifth Survey of Educational Research (vol. I \& II). (2000). New Delhi: NCERT.

[3] Sixth Survey of Educational Research (Vol. II). (2007). New Delhi: NCERT.

[4] Parliament of India. (1999). Eighty First Report on Value-based Education. Rajya Sabha Secretariat: New Delhi.

[5] Rokeach, Milton. (1973). The Nature of Human Values. New York: The Free Press.

[6] Feather, Norman T. (1975). Values in Education and Society. New York: The Free Press.

[7] Moral Decline. (1998, March 5). The Wall Street Journal, p. A14.

[8] Nussel, E. J. (1994). The American Value System: A Study in Contradictions. Phi Kappa Phi Journal, 23-29.

[9] Longstreth, L.E. (1979). Values in the Social Studies: Implicit, Explicit or Ignored, Social Education. In Kulshrestha, S.P. (Ed.), Emerging value-pattern of Teachers and New Trends of Education in India (p.39), Light and Life Publishers. New Delhi.

[10] Rajendra Prasad, D. (2006). The School, Teacher-Student Relations and Values. New Delhi: APH Publishing Corporation.

[11] Ray, D.K. (1988). Selection of Student Teachers: Predicting their Value Systems. In Kundu, C.L. (Ed.), Indian Year Book on Teacher Education (pp.173-174), New Delhi: Sterling Publishers Private Limited.

[12] Rita Coombs, Richardson \& Homer Tolson. (2005). A Comparison of Values Rankings for Selected American and Australian Teachers. Journal of Research in International Education, 4 (3), 263-277.

http://jri.sagepub.com/cgi/content/abstract /4/3/263
[13] Janusz, S. (2005). Values Preferred by Teachers and Students for Teacher Training Faculties. The New Educational Review, 7(3-4). http://www.educationalrev.us.edu.pl/ volume7.htm

[14] Escobar-Ortloff, L. M., \& Ortloff, W, G. (2000). Differences in Social and Moral Hierarchical Values among American Preservice Teachers and Professors. Paper presented at the Annual Meeting of the Society for the Philosophy and History of Education. September 30. Biloxi, MS.

[15] Rajendra Prasad, D. (2009). Value Orientation among Teacher Educators. New Frontiers in Education, 42(1), 53-59.

[16] Marks, M., \& Lemlech, J. (1979), Do the Values of Teacher Education Students Differ from the "Gatekeepers"? http://eric.ed.gov/?id=ED178517

[17] Zheng, H. (2009). A Review of Research on EFL Pre-Service Teachers' Beliefs and Practices. Journal of Cambridge Studies, 4(1), 80 .

[18] Mergler, A. G., \& Spooner-Lane, R. (2012). What Pre-service Teachers need to know to be Effective at Values-based Education. Australian Journal of Teacher Education, 37(8). 66-81. http://dx.doi.org/10.14221/ajte.2012v37n8.5

[19] Usha Sri, V. (1995). Restructuring Teacher Education for Value Orientation. Journal of Higher Education, 16(4), 601-649.

[20] Singh, L.C., \& Singh, P. (1986). Effectiveness of Value Clarification Strategies in Value Orientation of B.Ed. students. Report of ERIC Foundation Research Project, New Delhi: NCERT.

[21] Rajendra Prasad, D. (2008). Value Preferences and Value System among M.Ed. Students. Journal of Indian Education, 33(4), 21-22.

[22] Kakkar, S.B. (1992). Readings in Educational Psychology. Atlantic Publishers \& Distributors. http://books.google.co.in/books?id=MTvEoztS0tcC

[23] Bhushan, A. (1979). Values across Sex and Family Vocations, School of Education, Himachal Pradesh University. In Buch, M. B. (Ed.), (1987). Third Survey of Research in Education (p.113), New Delhi: NCERT.

[24] Nayyar, S. M. (1989). Closed Mindedness, Open Mindedness and Teacher Values of Student-teachers in Relation to Caste and Class. Indian Educational Review, 24 (1), 157-169. 
[25] Oguz, E. (2012). Views of Pre-service Teachers on Values and Value Education. Educational Sciences: Theory \& Practice. 12 (2) (Supplementary Special Issue).1320-1325. http://files.eric.ed.gov/fulltext/EJ987847.pdf
[26] Alkın Sahin, S., Tunca, N., Altınkurt Y., \& Yılmaz, K. (2016). Relationship between Professional Values and Critical Thinking Disposition of Science Technology and Mathematics Teachers. Eurasia Journal of Mathematics, Science \& Technology Education, 12(1), 25-40.

http://www.ejmste.com/ms.aspx?kimlik= $10.12973 \% 2$ feurasia. 2016.1371 a\&nerden $=2$ 